\title{
Article
}

\section{The Role of Anti-Dumping in the US-China Trade War}

\author{
Abdulkadir Yilmazcan ${ }^{*}$
}

The sudden escalation of the US-China trade war has negatively impacted global trade and the WTO, and its effects will last for a long time. This article centres on the US anti-dumping measures against Chinese exports within the trade war. The article attempts to explain the failure of the US trade policies in terms of anti-dumping measures; policies which were found to be inconsistent with the Anti-Dumping Agreement (ADA). Rather than complying with the Appellate Body Reports, the US insisted on using procedures inconsistent with the ADA, such as the zeroing methodology to overprotect the US industries. The US even blocked the appointment of Appellate Body Members and paralysed the WTO's Dispute Settlement Mechanism. Apart from political and economic reasons, one of the underlying reasons for the US to trigger a trade war with China would be anti-dumping measures. Antidumping measures are designed to balance unfair pricing strategies; however, the US is misusing the measures in order to avoid a trade deficit with China.

Keywords: Anti-Dumping, US-China Trade War, WTO, Anti-Dumping Agreement, Trade Remedies, NME

* Ph.D. candidate at the University of Hong Kong; Foreign Trade Expert at the Ministry of Trade, Turkey. M.A. (Ankara), LL.M. (Sussex). ORCID: https://orcid.org/0000-0002-5584-1232. The author may be contacted at: abdulkadiryilmazcan@yahoo.com/Address: HK Hong Kong Island Pok Fu Lam, 10/F, Cheng Yu Tung Tower, Centennial Campus, Pokfulam Road, The University of Hong Kong.

All the websites cited in this article were last visited on January 15, 2021. 


\section{INTRODUCTION}

This paper addresses the role of anti-dumping as an underlying reason for the US-China trade war. Since the declaration of additional duties on Chinese goods, more emphasis has been placed on the political and economic reasons for the trade war. This research investigates other pieces of evidence to understand the role of anti-dumping tensions in the trade war. It is not to claim that anti-dumping is the only motivation behind the US trade sanctions against China; however, the developments in anti-dumping practices may be one of the reasons for the US to adopt more direct measures such as additional duties based on the World Trade Organization (WTO)'s National Security exception. The General Agreement on Tariffs and Trade (GATT) Article XXI allows members to take appropriate measures to protect its essential security interests, as used by the US since 2017, ${ }^{1}$ but this mechanism has always been criticised as a huge loophole threatening the WTO system as a whole. ${ }^{2}$ In this context, initiating a trade war against China would be a policy shift from the anti-dumping investigations, as the WTO mechanism does not work in favour of the US anti-dumping practices.

China is traditionally the first target for anti-dumping measures to be enforced by the WTO members such as the US. ${ }^{3}$ Apart from being the top target, China has also been treated harshly by the US, as the intentional use of the zeroing methodology results in higher anti-dumping duties meaning more protection for the US industries. On the other hand, there are at least 30 Panel and Appellate Body Reports ruling that zeroing is a violation of the Anti-Dumping Agreement.

Base metals, machinery, electrical equipment, plastics and chemicals are the top sectors that the US is actively protecting through anti-dumping measures. These sectors constitute almost 80 percent of the trade deficit with China. 
Table 1: Trade Deficit of the US with China

\begin{tabular}{c|c|c|c|c}
\hline \multirow{2}{*}{ Industries } & \multirow{2}{*}{ HS Chapters } & \multicolumn{3}{|c}{ Trade Balance between the US and China } \\
\cline { 3 - 5 } & & $\mathbf{2 0 1 7}$ & $\mathbf{2 0 1 8}$ & $\mathbf{2 0 1 9}$ \\
\hline Chem \& Plastics & $27-40$ & $-11,732,607$ & $-17,678,063$ & $-15,531,872$ \\
\hline Textiles & $50-64$ & $-53,709,886$ & $-55,182,410$ & $-51,425,500$ \\
\hline Metals & $72-83$ & $-21,014,867$ & $-25,075,708$ & $-22,681,668$ \\
\hline Machinery & 84,85 & $-237,194,736$ & $-248,438,101$ & $-196,131,438$ \\
\hline Total (5 industries) & & $-323,652,096$ & $-346,374,282$ & $-285,770,478$ \\
\hline Total (all chapters) & & $-395,998,059$ & $-443,086,481$ & $-365,846,412$ \\
\hline$\%$ & & 82,7 & 78,1 & 78,1 \\
\hline
\end{tabular}

Source: TradeMap, available at https://www.trademap.org/Index.aspx.

Not surprisingly, these sectors have been covered by the trade sanctions against China since 2018. Within this context, apart from other factors, anti-dumping would be an underlying reason for the US to trigger a trade war against China. The author attempts to show the relationship between the US trade deficit, its antidumping measures, and additional tariffs.

The majority of the literature focuses on the outcomes of the trade war on the US and Chinese economies or its effects on other economies. Since 2018, the trade war has been in the news almost every day. However, the literature goes right back to the 2000s warning of a possible trade war between the US and China. Hughes refers to the expiry of the then 30-year-old Multifiber Arrangement (MFA), which limited exports by the signatories to prevent one country from holding a dominant position in the global markets. ${ }^{4}$ The share of Chinese global exports in textiles and clothing rose dramatically after the expiry of MFA. ${ }^{5}$ Aside from the dominance of China in textiles and clothing, Loridas acknowledges that what followed were the consecutive complaints of the US and China against each other under the WTO Dispute Settlement Mechanism, and the dissatisfactory outcomes encouraged the US retaliatory policies. ${ }^{6}$ Chow points out that due to the trade deficit of the US against China, the US uses double or triple trade remedies to suppress imports from China. ${ }^{7}$ This article also shows that the additional tariffs are not just about National Security concerns, but about the trade deficit with China and inappropriateness of the anti-dumping measures to avoid those deficits. The 
US anti-dumping practices are generally not approved by the Appellate Body, so that the US may bring the system into an impasse by not appointing the Appellate Body Members.

Studies after 2018 focus on the rapid developments and retaliatory measures taken by both sides. These studies also touch on the role of the WTO Dispute Settlement Mechanism (DSM) regarding the trade war. Hur emphasises the history of the US-China economic relations and the transformation of a long-lasting trade conflict into a trade war as a part of the hegemonic rivalry. ${ }^{8}$ Guohua underlines the role of the WTO rules and international law as balancers and coolers of the trade war. ${ }^{9}$ The author describes that the National Security exception of GATT Article XXI enables the US to conduct the Section 232 investigation on steel and aluminium, while China retaliates under GATT Articles I and II. ${ }^{10}$ Guohua, in another article, focuses on the WTO disputes since 2018 and labels the US as an "arrogant and irrational provocateur" of the tariff war, while China is forced to defend itself through the DSM. ${ }^{11}$ Nevertheless, the US may have justified reasons to instigate a trade war against China, since it has accused China of enforcing higher duties against the US, granting subsidies to Chinese firms, violating IP rights, and forcing US investors to transfer technology to domestic partners. ${ }^{12}$ China is also accused of devaluating its currency to boost exports. ${ }^{13}$ At the same time, the US has become dissatisfied with the WTO DSM. The failure of the Doha Round to revise the WTO agreements resulted in the Appellate Body being asked to fill the gaps or interpret the agreements. ${ }^{14}$ On the other hand, under Articles 3.2 and 19.2 of the Dispute Settlement Understanding, the Appellate Body or Dispute Settlement Body (DSB) cannot change the scope of rights of the WTO members. ${ }^{15}$

However, studies have shown that escalating tariffs in a retaliatory manner rather than using other negotiation mechanisms, results in the trade war between both parties harming their economies. ${ }^{16}$ For the US, these adverse effects include higher consumer prices and trade diversion in favour of other economies such as Taiwan, Mexico, the EU, and Vietnam. ${ }^{17}$ Circumvention will be another side effect of high tariffs. Chong and Li estimate that in the worst-case scenario, China will lose 1 percent of its GDP and unemployment will rise 1.1 points, ${ }^{18}$ so that the impact on China may not be as devastating as the US hopes. Furthermore, the National Security exception was not used meticulously in the US steel and aluminium case, which constitutes a bad-faith effort according to Patch. ${ }^{19}$ The author also evaluates the policy change from the 
multilateral to the unilateral route as bad-faith behaviour. ${ }^{20}$ Bown focuses on the reasons for the US policy shift after 40 years of special protection such as antidumping, countervailing, or safeguard measures into unilateral tariffs against China. $^{21}$ The author would argue that the US traditionally protected its domestic industries with such measures as anti-dumping, but Chinese subsidies and the Appellate Body's unfavourable reports triggered the US government to instigate a crisis with China. ${ }^{22}$ Bown underlines that this crisis, and blockage by the Appellate Body Members, have harmed the WTO in a way that would bring the system back to the pre-GATT94 era. ${ }^{23}$ The author views this as ironic, because the US was the complainant of the pre-GATT94 era during the 1980s, and used the Section 301 measures unilaterally, which ended up with the Uruguay Round and the formation of the rule-based system under the WTO. ${ }^{24}$ So, the US-China trade war might be an opportunity to reform the WTO considering the needs of all players. In addition to economic reasons, political reasons have also been discussed. Kim discusses the US fear of losing its hegemony over China as the underlying reason for the trade war. $^{25}$ Chong and Li argue that although the US-China trade war happens to be connected to economies, it is a politically-driven tension. ${ }^{26}$

The paper consists of five parts including Introduction and Conclusion. Part two will be devoted to the pre-trade war period which covers the establishment of the WTO to 2018. In this part, the accession of China to the WTO and nonmarket economy (NME) status is presented. The US anti-dumping practices, particularly against China, are also examined. Additionally, this part will focus on the controversial zeroing methodology and other anti-dumping cases against the US. The US continually uses the zeroing method by small alterations, even though the Appellate Body finds zeroing inconsistent with the Anti-Dumping Agreement (ADA) in several disputes. Anti-dumping is one of the reasons for the US to block the appointment of Appellate Body Members, which in turn deadlocks the respected WTO DSM. Part three will discuss the trade war period covering 2018 to 2021 for the scope of this study. The US policy of declaring a trade war against China and its political and economic effects are covered, along with the role of anti-dumping as a driving force of the US-China trade war. Part four will summarise the information presented in the previous sections and attempts to build a connection between the failure of the US to use anti-dumping investigations to protect its domestic industries and the trade sanctions against China under the 
national security exception of the GATT. Within this context, the paper shall bring anti-dumping to the forefront of the discussion concerning the US-China trade war. This will also highlight the abuse of anti-dumping measures under the international trade policy of the US.

\section{Pre-Trade War Period}

\section{A. China's Accession to the WTO and NME Status}

Becoming a GATT member in 1986, China applied for the WTO membership in 1995 and after a long negotiating process, the Accession Protocol was effective in $2001 .^{27}$ Seen as a threat to domestic industries, China faced reservations by other members which slowed the negotiations. The accession process was held in two independent tracks. The Working Party directed the multilateral track on China's Resumption of GATT Membership which was established in $1987 .^{28}$ The group then became the WTO Working Party on the Accession of China, in which 43 members discussed the draft protocol. ${ }^{29}$ There were also bilateral talks, especially with the US, on specific issues such as China's NME status.

\section{Issues and Challenges}

The participation of China as a WTO member was not easy compared to that of other countries. The protocol includes WTO-plus conditions for China, such as:

- the requirement that China liberalises the right to import and export goods for all enterprises in China (Article 5.1 of the Accession Protocol);

- the restriction on the Chinese Government from influencing or directing $\mathrm{SOEs}^{30}$ in import purchasing procedures (Article 6.1 of the Accession Protocol);

- the obligation to ensure "prices for traded goods and services in every sector to be determined by market forces" (Article 9.1 of the Accession Protocol);

- the agreement that subsidies granted to SOEs are deemed to be specific (Article 10.2 of the Accession Protocol);

- the obligation to eliminate all export taxes and charges (Article 11.3 of the Accession Protocol);

- the commitment to ensure that all SOEs and state invested enterprises "make purchases and sales based solely on commercial considerations," and that the Chinese Government does "not influence, directly or indirectly, commercial decisions" of these 
enterprises (paragraph 46 of the Working Party Report);

- the undertaking that price controls are not used "for purposes of affording protection to domestic industries or services providers" (paragraph 62 of the Working Party Report); and - a range of obligations on the publication of laws and regulations to ensure transparency (paragraphs $324-336$ of the Working Party Report). ${ }^{31}$

These are challenging concessions included in the Accession Protocol related to market access to goods and services, agriculture, subsidies, transparency, NME status in anti-dumping investigations, and safeguard investigations. ${ }^{32}$ However, China has agreed to comply with these substantive conditions during the negotiations because remaining outside of the WTO is even more costly than making these concessions. ${ }^{33}$ Furthermore, Chinese leaders evaluate the WTO as a driving force for reforms. ${ }^{34}$ The economic, legal, and political implications of accession to the WTO should be noted.

Within the context of economic implications, China has taken several steps, such as reducing the tariffs on agricultural products from 31.5 to 14.5 percent, as well as reducing tariffs on industrial products from 35 to 17 percent through $2004 .^{35}$ According to World Bank statistics, the weighted average of tariffs applied by China fell from 14.1 percent (2001) to 3.4 percent (2018). ${ }^{36}$ Foreign banks are allowed to operate in China and offer services in renminbi, and foreign companies are allowed to offer accounting and consultancy services. The investment banking industry also played a crucial role in economic growth and reforming State Owned Enterprises (SOEs) into market-driven entities.

The WTO accession also contributed positively in terms of legal implications. Legal reforms for the WTO accession elevate the rule of law while limiting the one-party rule. ${ }^{38}$ Another guarantee of the rule of law is the constitution, but the Chinese constitution is silent on the direct enforcement of international agreements such as the WTO accession. ${ }^{39}$ Still, substantive legal reforms were undertaken, such as foreign trade law, customs law, technical regulations, and IP law. ${ }^{40}$ As IP is the primary concern for other WTO members, China revised major IP laws such as Patent Law, Trademark Law, Copyright Law, as well as other regulations. ${ }^{41}$ Furthermore, specific IP crimes were added to the criminal laws. ${ }^{42}$ Yet, IP remains one of the main concerns for foreign companies doing business in China.

Overall, China liberated its market more than other major developing members. China also regulated its trade remedy legislation before the country's accession. 
Anti-dumping regulations were promulgated in 1997 and safeguard regulations in $2001{ }^{43}$ In this context, China initiated 294 anti-dumping investigations between 1998 and 2018 . $^{44}$ Two hundred and twenty of these investigations were affirmative by the adoption of anti-dumping measures. ${ }^{45}$ The top targets of Chinese anti-dumping investigations are the US, Japan, Korea and the EU, respectively. Compared to the WTO agreements, China's trade remedy regulations are undetailed. ${ }^{46}$

In terms of political implications, the WTO provides a forum for its members to discuss trade-related matters. It functions as a quasi-judicial legal process of interpretation by allowing members to negotiate national regulatory regimes and omit restrictive trade measures. ${ }^{47}$ In this regard, China's influence on the global economy is increasing. On the one hand, the WTO membership improves transparency and predictability, while, on the other, China initiated new policies such as the Belt and Road Initiative (BRI) or the Greater Bay Area (GBA) initiative to promote global integration. The BRI is one of the most significant regional economic development initiatives launched by China since 2013. ${ }^{48}$ Trade, investment, financial services, and innovation, are areas to be enhanced through the implementation period. The GBA initiative aims to improve socio-economic progress within southern China and create a solid starting point for the BRI. ${ }^{49}$

\section{NME status}

The basis of NME status can be traced back to GATT 1947, which is a part of GATT 1994. Article VI (Anti-dumping and Countervailing Duties) of GATT 1947 reads as follows:

1. The contracting parties recognize that dumping, by which products of one country are introduced into the commerce of another country at less than the normal value of the products, is to be condemned if it causes or threatens material injury to an established industry in the territory of a contracting party or materially retards the establishment of a domestic industry. For the purposes of this Article, a product is to be considered as being introduced into the commerce of an importing country at less than its normal value, if the price of the product exported from one country to another

(a) is less than the comparable price, in the ordinary course of trade, for the like product when destined for consumption in the exporting country, or,

(b) in the absence of such domestic price, is less than either

(i) the highest comparable price for the like product for export to any third country in the ordinary course of trade, or 
(ii) the cost of production of the product in the country of origin plus a reasonable addition for selling cost and profit.

This study assumes that markets operate at reliable prices. ${ }^{50}$ However, there may be cases in which domestic prices do not reflect the actual costs, which misleads the investigating authorities during the determination of the dumping margin. So, in the case of an NME, the highest comparable price of the like product will be taken into account for determining the dumping margin. A higher comparable price leads to a higher dumping margin and more anti-dumping protection. Therefore, being treated as an NME or market economy directly affects the export performance of any WTO member.

China's Accession Protocol had two substantive consequences in terms of China's NME status. First, the protocol implies that China can be treated as an NME and Chinese exporters need to prove that they are operating under market conditions. ${ }^{51}$ Second, Article 15 (d) sets the condition for China to be treated as a market economy based on the criteria of the importing members' national laws. ${ }^{52}$ This structure of the protocol leaves a lot of room for discretion in favour of the members other than China, whereby the same sector may be considered a market economy by one member while treated as an NME by another.

According to Chinese officials, China's NME status terminated in $2016^{53}$ However, members such as the EU are still finding alternative ways to treat China as an NME. The US also continues to treat China as an NME. This status inflates the anti-dumping margins and causes the anti-dumping laws to be over-protectionist. ${ }^{54}$ The policies of the EU and the US towards China will be examined in the forthcoming sections. In general, the concerns around the Chinese market are subsidies, cheap financing, and other benefits in favour of SOEs. ${ }^{55}$ It is also possible that these subsidies create inefficient SOEs. ${ }^{56}$ Other policies that affect China's market economy status are "export credits, and export credit insurance; public information services; assistance for exporters to explore international markets; setting up institutions to promote trade by developing foreign trade relations, sponsoring exhibitions, providing information and advisory services; and facilitating exports by small and medium-sized enterprises." ${ }^{, 57}$

After the termination of Article 15 (a)(ii) of the Accession Protocol, China carried the matter to the WTO DSM. China requested consultations under DS515 
against the US and DS516 against the EU. The consultations are still ongoing in terms of DS515. ${ }^{58}$ The Panel had been named for DS516 but lapsed in $2020 .{ }^{59}$

\section{B. The US Anti-Dumping Practices}

\section{Anti-dumping measures under the WTO regime}

Exporting products with lower prices compared to the home market selling price is called dumping. ${ }^{60}$ Dumping is price discrimination between markets. ${ }^{61}$ Antidumping measures are unfavourable for the exporting countries. Therefore, most of the measures are challenged before the DSM under the framework of the WTO $^{62}$ For instance, zeroing ${ }^{63}$ is the single most litigated issue under the WTO law. ${ }^{64}$ Tariffs and other trade policies are traditionally used by governments as boosters to the domestic industries. ${ }^{65}$

In the case of "zeroing," sales with negative dumping margins are omitted so that only dumped transactions are calculated. Zeroing is a calculation method which generally leads to a larger dumping margin. Because an anti-dumping investigation generally takes one or more years, some transactions may not be subject to dumping during this period. As a general rule, the average cost of these transactions should be calculated to find the dumping margin for a specific exporter. In the zeroing method, however, the investigating authority omits the transactions without dumping and only calculates the dumped transactions, thereby reaching a higher dumping margin. For instance, there are 10 export transactions where the exporter sold the goods below the home market price in five of the shipments. If the shipments without the dumped prices are taken into consideration, the average dumping margin will be lower and thus the final anti-dumping measure. In zeroing methodology, nonetheless only the dumped shipments are included to find the average dumping margin.

As the ADA has little to say on the procedural aspects of an anti-dumping investigation, the WTO members enforce their own procedural rules throughout an investigation. These procedures most often constitute a barrier for exporters, and as a result, exporters prefer not to cooperate. This, in turn, results in high antidumping duties, which defeats the main purpose of the Agreement.

\section{The US Anti-Dumping Practices and Appellate Body Rulings}

It is the case, in many disputes, that the US enforces strict procedural rules to extend 
the protectionist effects of anti-dumping measures, especially against China. Antidumping measures are criticised as being protective. This study holds the view that anti-dumping is not protective as long as procedural justice is secured by which more objective and unbiased outcomes can be achieved. However, if the investigating authorities use legal gaps, or take advantage of some provisions and apply excessively strict procedural rules aiming at higher duties, then the practice is protectionist.

The methodology of zeroing has a crucial role in the ongoing trade wars. ${ }^{66}$ This method results in higher anti-dumping duties, with the unclear wording of the ADA about allowing members to use zeroing. In addition, there are at least 30 Panel and Appellate Body decisions ruling that zeroing is a violation of the ADA. ${ }^{67}$ The US, in this vein, was found to be violating the ADA in several disputes.

In US-Zeroing (EC), the European Communities complained about the US's use of the zeroing methodology. The Panel distinguished between simple and model zeroing. Simple zeroing is the standard practice of omitting the transactions without dumping. Model zeroing means comparing weighted average prices on a model-by-model basis and omitting the models without a negative dumping margin. ${ }^{68}$ The Panel in this case ruled that the US acted inconsistently by applying zeroing at the original investigation, and decided not to use model zeroing due to judicial economy purposes. ${ }^{69}$ The Appellate Body holds its position that model zeroing is already found to be inconsistent with Article 2.4.2 of the ADA, and highlights that the Panel is right to skip this argument. ${ }^{70}$

In US-Zeroing (Japan), Japan brings the same arguments against the US Department of Commerce (DOC)' practice of model zeroing. ${ }^{71}$ The Panel finds the DOC's practise of model zeroing inconsistent with the ADA, but does not find simple zeroing as inconsistent. According to the Appellate Body, disregarding the models with negative dumping margin results in an unfair comparison since the product as a whole is not evaluated, and thus model zeroing is found inconsistent with the ADA. Furthermore, the Appellate Body reversed the Panel decision on simple zeroing and found it also inconsistent as a $\mathrm{T}^{-\mathrm{T}^{72}}$ comparison as all transactions need to be covered to achieve a fair comparison. ${ }^{73}$

In terms of all WTO disputes, China brought 16 cases against the US, five of which relate to anti-dumping measures. ${ }^{74}$ Meanwhile, the US brought 23 cases against China, covering anti-dumping measures as well as IP rights, export restrictions, and subsidies on a number of industries. 
In US-Anti-Dumping and Countervailing Duties (China), China brought several issues before the WTO DSM. The Panel ruled in favour of the US, that China was not able to establish the issue on double remedies. The Appellate Body, however, reversed the Panel decision on the basis that imposition of both anti-dumping measures and countervailing measures constitutes a violation of the Agreement on Subsidies and Countervailing Measures (SCM Agreement). ${ }^{75}$ Double remedies offset the same subsidisation twice, thereby over-protecting the local industries of the importing countries. Within this case, the US had four sets of measures adopted at the same time. Consequently, the Appellate Body requested that the US make its measures consistent with the SCM Agreement. ${ }^{76}$

In US-Countervailing and Anti-Dumping Measures (China), the Panel found that the US acted inconsistently in not avoiding double remedies on the same imported products. This issue was not appealed, and therefore finalised. ${ }^{77}$

In US-Anti-Dumping Methodologies (China), China challenged the application of a single rate against Chinese firms. ${ }^{78}$ China argued that the application of a single rate presumption for all non-market entities is inconsistent with Articles 6.10 and 9.2 of the ADA. ${ }^{79}$ The Panel agreed with China based on previous Appellate Body Reports interpreting the above-mentioned articles as obliging investigating authorities to calculate dumping margins individually. ${ }^{80}$ In terms of NME, exporters should have the chance to prove that they are not operating under government control. This case is also a remarkable; when the Panel was discussing the methodologies used, the US shifted from targeted dumping into another methodology so that they could claim the measure was in conformity when the report was published. ${ }^{81}$ Also, the Appellate Body ruling on allowing investigating authorities to calculate average prices to reach a pattern, and not requiring the investigating authorities to disclose the explanations for the pattern, may result in new targeted dumping disputes. ${ }^{82}$

In a more recent case, US - Differential Pricing Methodology on targeted dumping, the Panel found zeroing permissible. ${ }^{83}$ Thus, the zeroing issue became a hot topic again as the Panel did not follow the past Appellate Body rulings. However, the problem in practice is that due to the US's strategy of blocking newly appointed members to the Appellate Body, the appeals procedure for this Panel Report is compelling, as the Appellate Body is not able to work since new members have not been appointed. 


\section{Trade War Period}

\section{A. The US Declaration of Trade War against China}

The US foreign trade policy towards China was getting more tense for decades due to the high trade deficit, IP violations, forced transfer of technology, tech wars, currency manipulation, investment overseas, and subsidies. After accession to the WTO, China gained advantages in terms of market access to global markets. Due to cost advantages, many American brands shifted their manufacturing operations to China. Eventually, the Chinese economy improved with astonishing speed. China became world's largest exporter in 2009 surpassing Germany and the US. ${ }^{84}$ It is also forecasted that China will surpass the US in terms of aggregate real GDP around $2030 .^{85}$ These tensions turned into direct policy measures after the 2016 presidential election in the US; since then, the US-China trade war has become the new normal as expressed by Lau. ${ }^{86}$

President Trump gave the first signs of a commercial policy change towards China during his campaign in 2016. The following year, the Office of the United States Trade Representative (USTR) was authorised to investigate the steel/ aluminium imports in terms of national security, and the trade talks between the US and China failed in the same year. ${ }^{87}$ In 2018, there was another phase, in which the US began to target Chinese solar panels, washing machines, steel, and aluminium exports. ${ }^{88}$ While the measures taken by the US against other countries such as Canada and Mexico were mainly settled by negotiation, China retaliated with tariff increases on more than one hundred US products. By the end of 2018, the US took additional measures affecting USD200 billion worth of Chinese exports, while China retaliated against it with tariff increases on US exports worth USD60 billion. This increase resulted in 12 and 18 percent average tariffs in the US and China, respectively. ${ }^{89}$ Due to trade talks between the US and China, tariffs decreased slightly in the first half of 2019. In the second half of 2019, however, the US adopted measures of up to USD300 billion, while China's measures hit USD75 billion, ${ }^{90}$ thereby carrying the tariff average rates to 21.1 and 21 percent, respectively. ${ }^{91}$ Even the phase one trade deal in February 2020 between the parties decreased the average level of tariffs by only around 1 percent, having little impact on the bilateral trade. ${ }^{92}$ 


\section{The economic effects of measures}

The trade war between the US and China affects USD550 billion worth of Chinese products and USD185 billion worth of US products. ${ }^{93}$ Additional tariffs mean it will be costlier to import products bilaterally. In this vein, the first victims will be the consumers, as the increased costs will be passed on to them. ${ }^{94}$ Companies investing overseas are also negatively affected by the countries' tense relationship. ${ }^{95}$ However, some companies such as Tesla are investing in China to tariff-jump, while having better access to the fast-growing Chinese market.

Due to the trade war, exports, employment and consumption are reduced, leading to welfare losses. ${ }^{96}$ Also, as some of the additional duties have been levied upon raw materials such as aluminium and steel, manufacturer costs have risen, such as those of the automobile industry on the US side.

Trade will divert as in other bilateral protectionist measures. This will also result in manufacturing capacity shifts from China to other countries such as Vietnam. ${ }^{97}$ Since some factories textiles or plastics, however, cannot easily move to other countries, the tariffs are expected to be circumvented. ${ }^{98}$ The US DOC already proposes to tighten the anti-dumping regulations to avoid circumvention of the duties. ${ }^{99}$ Vietnam may be also a hot spot for Chinese manufacturers, because the Free Trade Agreement between the EU and Vietnam was signed in early 2020. ${ }^{100}$ Apart from the trade diversion effects, investment rates will also decline due to uncertainty. Company divorce rates will increase due to national security concerns. ${ }^{101}$

The city of Hong Kong is another political issue with economic consequences. Hong Kong's draft bill on the extradition of offenders with China, resulted in pro-democracy protests starting in the summer of 2019 and public unrest. The US used the situation to suppress China in the international arena politically and economically. As of August 2020, Hong Kong lost its special trading status granted by the US under the US-Hong Kong Policy Act of 1992. For this impact, Hong Kong will no longer be able to enjoy its special status, but be treated like China in terms of customs rules. In this regard, the US first banned the export of dual-use products to Hong Kong, and then required Hong Kong exports to be labelled as "Made in China." ${ }^{, 122}$ Accordingly, the logistics sector is expected to be negatively affected by the US-China trade war as Hong Kong plays a crucial role in the re-export of products to the US. ${ }^{103}$

Overall, the common wisdom suggests that the economic effects will be 
negative for both sides, but the US will be affected more deeply. The US companies in China and Hong Kong will be negatively affected akin to the Chinese companies in the US. It is also notable that the US trade deficit is not only against China, but against several countries for many years. ${ }^{104}$ Figure 1 below shows the trade balances of the US and China over the years. It seems that the trade war has affected the US worse than China. Figure 2 shows that the core inflation rate decreased sharply in the US, whereas China managed to lower inflation. Figure 3 shows GDP growth rates, and in early 2020 both economies plunged. In the second quarter of 2020, while China recovered, the US economy suffered further, shrinking by 30 percent. The reason for the sharp decline in respective GDP is the lockdown in both economies due to the COVID-19 pandemic.

Figure 1: US - China Balance of Trade Comparison ${ }^{105}$

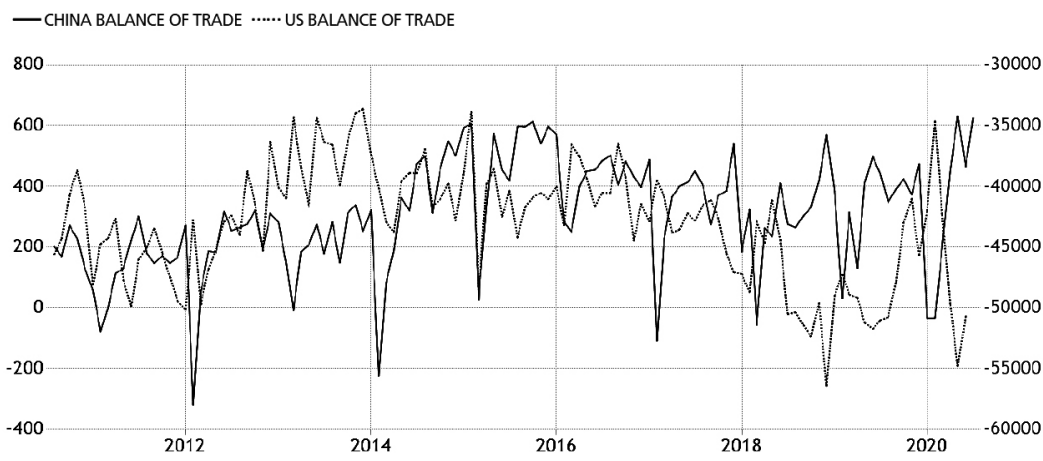

Figure 2: US - China Core Inflation Rate Comparison ${ }^{106}$

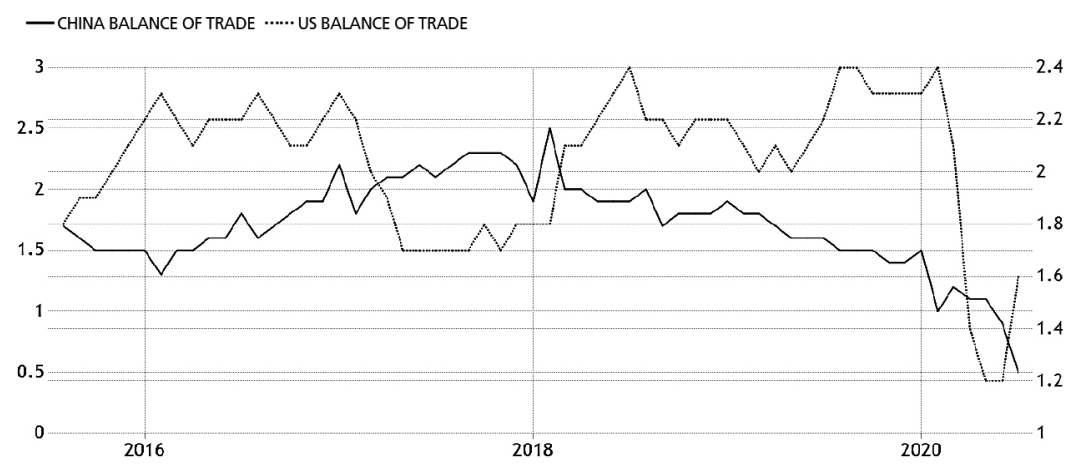


Figure 3: US - China GDP Growth Rate Comparison ${ }^{107}$

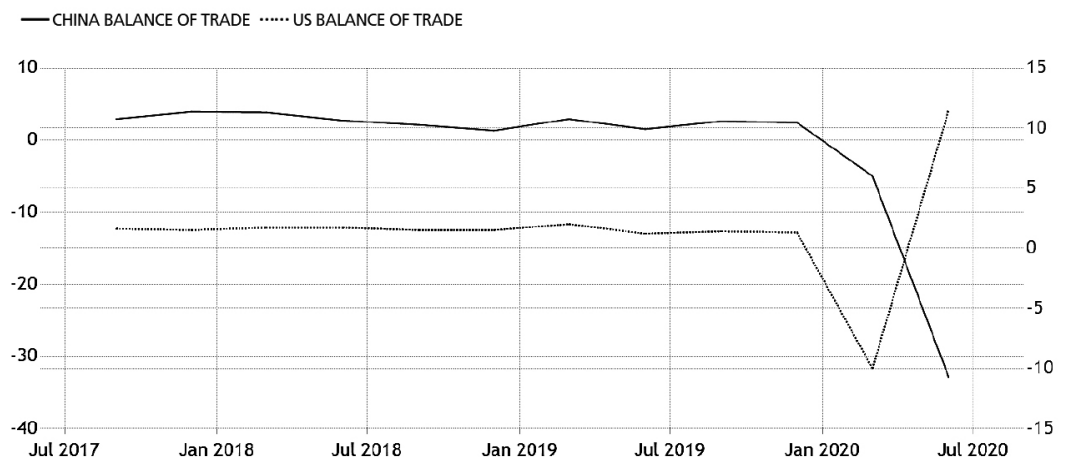

Another economic effect has originated from the WTO DSM. In late 2018, China challenged the additional tariffs adopted by the US. In the United States-Tariff Measures on Certain Goods from China, China argued that the additional tariffs under List 1 (USD34 B) and List 2 (USD200 B) are inconsistent with the mostfavourite nation and bound tariff rates. Even though the Appellate Body has not functioned since December 2019, the Panel circulated a report in September 2020 acknowledging China's arguments and finding the US lists inconsistent with Articles I:1, II:1(a) and II:1(b) of GATT 1994. ${ }^{108}$ According to the Panel Report, the US also failed to demonstrate that the measures are justifiable under the general exemptions in GATT $1994 .^{109}$ However, China had already retaliated against the US measures, and accordingly, parties have been engaged in trade negotiations outside the WTO. Also, as the Appellate Body is presently not functioning, the Panel Report cannot currently be appealed.

\section{The Political Effects of Measures}

The motivation of the trade war is rather political. ${ }^{110}$ President Trump promised to fight against Chinese imports during his election campaign, and after he came to power the trade war was triggered by the steel/aluminium investigation. Some articles show that Chinese imports to the US caused unemployment and lower wages, which is targeted by President Trump as a policy objective. ${ }^{111}$ Aside from the huge trade deficit, the US also accuses China of forced technology transfer, currency manipulation, subsidies, etc. China is labelled as a strategic rival and 
adversary even in official documents of the US. ${ }^{112}$ With the escalation of the trade war, further protectionist measures are adopted. The US levied measures against the EU, Canada, and Mexico on steel. NAFTA ${ }^{113}$ was revised, and the EU retaliated with additional duties on products such as motorcycles.

Meanwhile, as mentioned above, the US blocked the WTO DSM by not appointing Appellate Body Members, which resulted in a crisis in the WTO. The EU proposed the "Interim Appeal Arbitration Pursuant to Article 25 DSU," aimed at settling disputes until the Appellate Body is once again functioning. ${ }^{114}$ The proposal became effective with the signature of the multi-party interim appeal arbitration arrangement (MPIA) to the WTO by 19 WTO members in April 2020. ${ }^{115}$ Due to the shift from rule-based to power-based policies, the global trading system is being hurt, and more WTO members are following protectionist policies. The political risk in Asia is increasing as the US is also threatening to use the measures against Vietnam. ${ }^{116}$ This trend brings de-globalisation rather than globalisation. ${ }^{117}$

Besides its economic implications, the trade war tightened the political tensions between the US and China. Hong Kong, Taiwan, and Xinjiang are the other political factors, together with the Huawei case. The US adopted sanctions against top Hong Kong officials including the Chief Executive. ${ }^{118}$ Meanwhile, the trade talks resulted in the phase one trade deal between the US and China in early 2020. The deal covered some commitments for China to buy more US products and improve IP regulations, while for the US to cut the additional tariffs to a certain level. ${ }^{119}$ This was expected to ease the tensions to some extent but, in fact, the opposite has happened since the deal. The COVID-19 pandemic has negatively affected relations again, and the US has accused China of being the source of the virus. The GDP shrinkage is also related to the lockdowns resulting from the pandemic, so that blaming China would be seen as a political move to distract the American citizens. The current situation is summarised by Crabtree:

US-China relations are at their worst point in living memory for a number of decades, probably since the 1970s. At the moment there's a grand exercise in blame shifting going on, on both sides... Neither side wants to be blamed for their own response, so the Chinese and Americans are blaming each other. ${ }^{120}$

In July 2020, the US requested the closure of the Chinese consulate in Houston, 
which led China to retaliate against it with the closure of the US consulate in Chengdu. In consequence, the political impact could have been deteriorated if President Trump had won the election in November 2020 and China continued to retaliate against the US measures. At the same time, China is going forward with other policy objectives such as the BRI, to increase its regional and global influence.

\section{B. Anti-Dumping as a Driving Force of the US-China Trade War}

Table 2 shows that the product groups in which the US has the highest trade deficit to China have been compared to the US anti-dumping orders against China. These products have also been searched in the US additional tariff lists.

Table 2: US Anti-dumping Measures Matching with the Trade Deficit and Additional Tariffs ${ }^{121}$

\begin{tabular}{c|c|c|c}
\hline $\begin{array}{c}\text { USITC AD orders product description } \\
\text { 2017, 2018, 2019) }\end{array}$ & $\begin{array}{c}\text { Trade balance } \\
\text { 3 years average } \\
\text { (1000 USD) }\end{array}$ & US Lists & $\begin{array}{c}\text { Additional } \\
\text { duty rate }\end{array}$ \\
\hline Steel Racks & $-7,060,107$ & List 3 & $25 \%$ \\
\hline Tool Chests and Cabinets & $-5,759,818$ & List 3 & $25 \%$ \\
\hline Vertical Metal File Cabinets & $-4,160,813$ & List 3 & $25 \%$ \\
\hline Steel Wheels & $-3,069,294$ & List 3 & $25 \%$ \\
\hline Biaxial Integral Geogrid Products & $-1,464,226$ & List 3, List 4A & $25 \%, 7.5 \%$ \\
\hline Hardwood Plywood Products & $-1,411,049$ & List 3, List 4B & $25 \%, 15 \%$ \\
\hline Mattresses & $-1,366,376$ & List 3 & $25 \%$ \\
\hline Quartz & $-1,005,723$ & List 3 & $25 \%$ \\
\hline Truck and Bus Tires & $-860,918$ & List 3 & $25 \%$ \\
\hline Steel Trailer Wheels & $-658,662$ & List 3 & $25 \%$ \\
\hline Rubber Bands & $-421,920$ & List 3 & $25 \%$ \\
\hline 1-Hydroxyethylidene-1, & $-420,373$ & List 4B & $15 \%$ currently \\
\hline 1-Diphosphonic Acid (HEDP) & $-400,940$ & List 2, List 4B & $25 \%, 7.5 \%$ \\
\hline Plastic Decorative Ribbon & $-384,014$ & List 3, List 4A & $25 \%, 7.50 \%$ \\
\hline Carton-Closing Staples & $-354,105$ & List 3 & $25 \%$ \\
\hline Forged Steel Fittings & & &
\end{tabular}




\begin{tabular}{|c|c|c|c|}
\hline 1,1,1,2 Tetrafluoroethane (R-134a) & $-322,952$ & List 4B & $\begin{array}{l}15 \% \text { currently } \\
\text { suspended }\end{array}$ \\
\hline Aluminum Foil & $-243,845$ & List $4 \mathrm{~A}$ & $7.50 \%$ \\
\hline Aluminum Wire and Cable & $-235,793$ & List 1 & $25 \%$ \\
\hline $\begin{array}{c}\text { Cold-Drawn Mechanical Tubing } \\
\text { of Carbon and Alloy Steel }\end{array}$ & $-226,857$ & List 4A & $7.50 \%$ \\
\hline Fine Denier Polyester Staple Fiber & $-149,849$ & List 3 & $25 \%$ \\
\hline Sodium Gluconate & $-144,148$ & List 3 & $25 \%$ \\
\hline Refillable Stainless Steel Kegs & $-139,926$ & List 3 & $25 \%$ \\
\hline Carbon and Alloy Steel Cut-to-Length Plate & $-139,233$ & List 4A & $7.50 \%$ \\
\hline Large Residential Washers & $-112,078$ & List 4A & $7.50 \%$ \\
\hline Steel Propane Cylinders & $-83,515$ & List 3 & $25 \%$ \\
\hline Stainless Steel Flanges & $-15,063$ & List 3 & $25 \%$ \\
\hline Cast Iron Soil Pipe Fittings & $-14,391$ & List 3 & $25 \%$ \\
\hline Cast Iron Soil Pipe & $-14,391$ & List 3 & $25 \%$ \\
\hline Common Alloy Aluminum Sheet & $-11,390$ & List 4A & $7.50 \%$ \\
\hline Stainless Steel Sheet and Strip & $-10,328$ & List 4A & $7.50 \%$ \\
\hline Amorphous Silica Fabric & $-8,107$ & List 3, List 4A & $25 \%, 7.5 \%$ \\
\hline Large Diameter Welded Pipe & $-4,641$ & List 4A & $7.50 \%$ \\
\hline Ammonium Sulfate & -11 & List 3 & $25 \%$ \\
\hline $\begin{array}{c}\text { Total deficit subject to anti-dumping } \\
\text { measures ( } 3 \text { years average) }\end{array}$ & $-30,674,855$ & & \\
\hline $\begin{array}{c}\text { Total trade deficit on all items } \\
\text { (3 years average) }\end{array}$ & $-401,643,651$ & & \\
\hline Percentage & 7.6 & & \\
\hline
\end{tabular}

First, the data in the table suggests that the US has been traditionally protecting its domestic industries by anti-dumping measures. There are 33 anti-dumping measures between 2017 and 2019. Recalling Table 1 above, ${ }^{122} 79$ percent of the investigations conducted within the last three years fall in the top 5 industries where the US has a trade deficit with China. The products covered by antidumping measures constitute around 8 percent of the total trade deficit on the 3 -year average. This trend shows that there is a relationship between the US anti- 
dumping policy and its trade war strategy with China. The Trump administration adopted 260 percent more anti-dumping and countervailing measures compared to the Obama administration. ${ }^{123}$ Notably, 29 of these measures are also accompanied by countervailing measures. ${ }^{124}$ The practice of double remedies was found to be in violation of Article 19.3 of the SCM Agreement. ${ }^{125}$ However, the US insists on using double remedies despite these rulings. Because the US had already lost several cases at the WTO primarily on zeroing, it also blocked the appointment of the WTO Appellate Body Members. Therefore, the US excessively adopts antidumping and countervailing measures to cut the trade deficit with China.

Second, in addition to anti-dumping duties, all of these products were protected with additional tariffs under the US lists. These duties range from 7.5 to 25 percent, which is a significant barrier to trade. The 7.5 percent rate is a cut-off as a commitment to the phase one trade deal; the original rate for these products was 15 percent. ${ }^{126}$ Generally, anti-dumping measures adopted by the US are much higher than those rates. Mattresses from China are an exceptional case for anti-dumping practices, with 1700 percent's anti-dumping measures.

According to Table 2, all the products protected with an anti-dumping duty retain a trade deficit, and they have also been protected with additional duties since the beginning of the trade war. The trade deficit is not a prerequisite of adopting an anti-dumping duty under the WTO law. However, the US practice cast doubt on the real purpose behind the adoption of the anti-dumping duties. The US measures seem to be used as a barrier against Chinese exports.

\section{Conclusion: Post-Trade War Period}

This study attempts to demonstrate that anti-dumping practices of the US against China have had an impact on the current US-China trade war. It does not mean that anti-dumping is the only and essential reason for the trade war. The US conventionally uses anti-dumping measures to protect its domestic industries and reduce its trade deficit. The US anti-dumping measures are levied upon the products with a trade deficit over China. And some cases, such as mattresses, ${ }^{127}$ prove that anti-dumping is being used as a protectionist tool rather than balancing the price differences in markets. 
At the WTO level, the US is unsatisfied with the rulings of the Appellate Body. Calculation methods such as zeroing have been found inconsistent with the ADA in many disputes, requiring the US government to recalculate and lower the margins in question. Rather than complying with the Appellate Body rulings, however, the US blocked the appointment of new members to lock down the DSM.

On a bilateral level, the US adopted additional tariffs exceeding its WTObound rates against China covering USD550 billion worth of Chinese products. Recently, the WTO Panel found that these measures are inconsistent with the most favoured nation principle as well as with the bound tariff rates. ${ }^{128}$ Further protectionist measures were also adopted against other economies such as the EU, Canada, and Mexico, showing the overall international policy change by the US. In any case, the main target is China, and due to the immediate retaliation, the trade war escalated, causing concerns for the global trading system and the political situation.

The US has used the DSM extensively against China in 23 cases up to now. ${ }^{129}$ China also sued the US 16 times, mostly on trade remedies. ${ }^{130}$ Since the beginning of the trade war in early 2018, China has been more active in filing six disputes against the US. ${ }^{131}$ The US filed only two cases against China regarding IP rights and additional tariffs. Due to the US blockade of the Appellate Body Members, however, the role of the WTO as a forum for trade negotiations is questioned. Liu and Woo assert; "Economic disputes are a systemic feature of the present uncoordinated multipolar political order." ${ }^{, 132}$ Therefore, instabilities in global politics adversely affect free and fair trade. Conversely, economic problems between nations can cause political tensions. The rise of the Chinese economy brought tensions among other countries, such as the US. Since the accession of China to the WTO, the US has protected its domestic industries by adopting antidumping measures just like other WTO members. However, the problem is that anti-dumping is not designed to handle the trade deficit, and the protectionist purposes are overruled by several DSB rulings. This has also affected the US policies towards the WTO and its DSB.

The US blockade of the Appellate Body Members and the trade war can be considered as a shift from the rules-based to a power-based system, which risks the free and fair trade and deglobalizes the world. The huge shrink of the US GDP 
in the first half of 2020 demonstrates the negative outcomes of such policies, even though some can be linked to the pandemic. The US policies further resulted in a crisis at the WTO, as the Director-General stepped down in August 2020. The expectation is that the new Director-General will handle the deep clash of interests between the developed and developing nations, and successfully lead to reform of the WTO, which also depends on how the members learn the lessons from the past protectionism periods.

\section{REFERENCES}

1. US Department of Commerce was authorised to investigate the steel under Section 232 of the Trade Expansion Act of 1962 (19 U.S.C. $\S 1862$ ) to evaluate the effects of imports on national security. For details, see the official website of the US Dept. of Commerce, available at https://www.commerce.gov/section-232-investigation-effect-imports-steel-usnational-security\#factsheetwh.

2. S. Kho \& T. Petersen, Turning the Tables: The United States, China, and the WTO National Security Exception, CHINA Bus. Rev., Aug. 19, 2019, available at https://www. chinabusinessreview.com/turning-the-tables-the-united-states-china-and-the-wto-nationalsecurity-exception.

3. WTO, Anti-dumping measures: reporting Member vs Exporter, (2021), available at https:// www.wto.org/english/tratop_e/adp_e/adp_e.htm.

4. N. C. Hughes, A Trade War with China, 84 (4) Foreign Aff. 94-106 (2005).

5. Textiles export share of China rose from $10.3 \%$ to $37.6 \%$ between 2000 and 2018. At the same time, clothing export share of China rose from $18.2 \%$ to $31.3 \%$. See World Trade Statistical Review 2019, available at https://www.wto.org/english/res_e/statis_e/wts2019_ e/wts19_toc_e.htm. For details on an economic analysis of the expiry of the Multifiber Agreement, see I. Brambilla \& A. Khandelwal \& P. Schott, China's experience under the multi-fiber arrangement (MFA) and the agreement on textiles and clothing (ATC), in China's Growing Role in World Trade 345-87 (R. Feenstra \& S. Wei eds., 2013).

6. K. Loridas, United States-China Trade War: Signs of Protectionism in a Globalized Economy 34 Suffolk Transnat'l L. Rev. 403 (2011).

7. E.g., increased tariffs, additional taxes, anti-dumping, countervailing duties or safeguards. See D. Chow, China's Coming Trade War with the United States, 81 UMKC L. Rev. 257 (2012). 
8. Nany Hur, Historical and Strategic Concern Over the US-China Trade War: Will They Be within the WTO, 11 J. East AsIa \& INT'L L. 393 (2018).

9. Y. Guohua, International Law in the 2018 China-US Trade War, 9(1) J. WTO \& CHINA 2855 (2019).

10. Id.

11. Id. at 69 .

12. C. Bown, The 2018 US-China Trade Conflict After 40 Years of Special Protection, 12(2) China Econ. J. (2019). See also supra note 8; A. Zhang, The US-China Trade Negotiation: A Contract Theory Perspective, 51 Georgetown J. InT'L L. (2020).

13. C. Li \& C. He \& C. Lin, Economic Impacts of the Possible China-US Trade War, 54 (7) J. EMERging Mкt. Fin. 1558 (2018).

14. T. Payosova \& G. Hufbauer, \& J. Schott, The Dispute Settlement Crisis in the World Trade Organization: Causes and Cures, Peterson Institute for International Economics Policy Briefs (PB18-5, 2018), available at https:/www.piie.com/publications/policy-briefs/ dispute-settlement-crisis-world-trade-organization-causes-and-cures.

15. Id.

16. T. Fetzer \& C Schwarz, Tariffs and Politics: Evidence From Trump's Trade Wars (CESifo Working Paper No. 7553, 2019).

17. A. Nicita, Trade and Trade Diversion Effects of United States Tariffs on China (UNCTAD Research Paper No. 37, 2019).

18. T. Chong \& X. Li, Understanding the China-US Trade War: Causes, Economic Impact, and the Worst-Case Scenario, 7(2) Econ. \& Political Stud. 185-202 (2019).

19. C. Patch, A Unilateral President vs. A Multilateral Trade Organization: Ethical Implications In The Ongoing Trade War, 32 Geo. J. Legal Ethics 883 (2019).

20. Id.

21. Bown, supra note 12.

22. Id.

23. C. Bown, The 2018 Trade War and the End of Dispute Settlement as We Knew It, in Trade War: The Clash of Economic Systems Endangering Global Prosperity 21-32 (M. Crowley ed., 2019).

24. Id.

25. Min-hyung Kim, A Real Driver of US-China Trade Conflict, 3(1) Int'L Trade, Politics \& Dev. 30-40 (2019).

26. Supra note 18 , at 188.

27. J. Telep \& R. Lutz, China's Long Road to Market Economy Status, 49 Geo. J. InT'L L. 693 (2017).

28. W. Zhou \& D. Peng, EU-Price Comparison Methodologies (DS516): Challenging the Non-Market Economy Methodology in Light of the Negotiating History of Article 15 of China's WTO Accession Protocol, 52 (3) J. WorLd TRADE 518 (2018). 
29. WTO, Accessions: China, (2020) available at https://www.wto.org/english/thewto_e/acc_ e/al_chine_e.htm.

30. State Owned Enterprises.

31. Zhou \& Peng, supra note 28, at 533.

32. K. Halverson, China's WTO Accession: Economic, Legal, and Political Implications, 27 BC INT'L \& Comp. L. Rev. 327 (2004).

33. Id. at 332 .

34. Yong Wang, How WTO Accession Has Changed China and the Road Forward: Looking Back, Looking Forward: China and the World Trade Organization 10 Years after Accession (May 19, 2011), available at https://www.cigionline.org/publications/how-wtoaccession-has-changed-china-and-road-forward.

35. G. Chow, The Impact of Joining WTO on China's Economic, Legal and Political Institutions, 8(2) PAC. ECON. Rev. 105-15 (2003).

36. The World Bank Data, available at https://data.worldbank.org/indicator/TM.TAX.MRCH. WM.AR.ZS?locations $=\mathrm{CN}$.

37. A. Douglas \& A. Huang, Investment Banking in China: Past, Present and Future, in China's Capital Markets: Challenges from WTO Membership 141 (K. Chan \& H. Fung eds., 2007).

38. Supra note 35, at 111.

39. Julia Ya Qin, Trade, Investment and Beyond: The Impact of WTO Accession on China's Legal System, in Law and The Market Economy in China 271 (P. Keller ed., 2017).

40. Id. at 272 .

41. Id. at 284 .

42. Id.

43. Id. at 274.

44. WTO, Antidumping statistics, available at https://www.wto.org/english/tratop_e/adp_e/ adp_e.htm.

45. Id.

46. Supra note 39, at 727.

47. D. Kennedy, Law and Development Economics: Toward a New Alliance, in LAW AND Economics with Chinese Characteristics: Institutions for Promoting Development in the Twenty-First Century 65 (D. Kennedy \& J. Stiglitz eds. 2013).

48. C. H. Chen, ASEAN financial integration and the Belt and Road Initiative: Legal challenges and opportunities for China in Southeast Asia, in InTERnATIONAL Governance and the Rule of Law in China under the Belt and Road Initiative 163 (Yun Zhao ed., 2018).

49. Greater Bay Area Overview, available at https://www.bayarea.gov.hk/en/about/overview. html.

50. A. Washington, Not So Fast, China: Non-Market Economy Status Is Not Necessary for the 
Surrogate Country Method, 19 ChINESE J. INT'L L. 262 (2018).

51. L. Puccio, Granting Market Economy Status to China, An Analysis of WTO Law and of Selected WTO Members' Policy (European Parliamentary Research Service, NovemberPE 571, 2015), at 5.

52. CAP art. 15 (d). See Protocol of Accession, WTO Doc. WT/L/432, available at https:// www.wto.org/english/thewto_e/acc_e/al_chine_e.htm.

53. Weihuan Zhou, China's Litigation on Non-Market Economy Treatment at the WTO: A Preliminary Assessment, 5(2) ChINeSE J. COMP. L. 345-64 (2017).

54. Weihuan Zhou \& A. Percival, Debunking the Myth of 'Particular Market Situation' in WTO Antidumping Law, 19(4) J. InT’L. Econ. L. 865 (2016).

55. A. Kroeber, China's Economy: What Everyone Needs To Know 241 (2016).

56. Id.

57. Bin Xu, Trade Policy Reform and Trade Reform, in The Oxford Companion to the EConomics of China SHengGen 157 (S. Fan et al. eds., 2014).

58. WTO, DS515: United States - Measures Related to Price Comparison Methodologies, available at https://www.wto.org/english/tratop_e/dispu_e/cases_e/ds515_e.htm.

59. WTO, DS516: European Union - Measures Related to Price Comparison Methodologies, available at https://www.wto.org/english/tratop_e/dispu_e/cases_e/ds516_e.htm.

60. P. Van Den Bossche, L. Henry \& W. Zdouc, The Law and Policy of the World Trade Organization: Text, Cases and Materials 697 (4th ed. 2017).

61. R. Krishna, Anti-Dumping in Law and Practice, The World Bank E-Library 6 (1999) available at http://documents1.worldbank.org/curated/en/917451468739567805/10450432 2_20041117163012/additional/multi-page.pdf.

62. B. Hoekman \& P. Mavroidis, World Trade Organization (WTO): Law, Economics, and Politics 1 (2007).

63. Zeroing is a calculation method which generally leads to a larger dumping margin. As a general rule the average of these transactions should be calculated in order to find the dumping margin for a specific exporter. See T. Prusa \& E. Vermulst, United StatesContinued Existence and Application of Zeroing Methodology: The End of Zeroing?, 10(1) World Trade Rev. 45-61 (2011).

64. Id. Some examples focusing on the zeroing issue would be: US-Use of Zeroing in AntiDumping Measures Involving Products from Korea (DS 402); US-Continued Existence and Application of Zeroing Methodology (DS 350); or US-Measures Relating to Zeroing and Sunset Reviews (DS 322).

65. J. Brander \& B. Spencer, Tariff Protection and Imperfect Competition, in ImPERfect Competition and International Trade 107 (G. Grossman ed., 1992).

66. Supra note 63.

67. P. Mavroidis \& T. Prusa, Die Another Day: Zeroing in on Targeted Dumping-Did the AB Hit the Mark in US-Washing Machines?, 17(2) World Trade Rev. 241 (2018). 
68. E. Vermulst \& D. Ikenson, Zeroing under the WTO Anti-Dumping Agreement: where do we stand, 2 Global Trade \& Customs J. 235 (2007).

69. Panel Report, United States- Laws, Regulations and Methodology for Calculating Dumping Margins (Zeroing), WTO Doc. WT/DS294/R 70 (adopted Oct. 31, 2005).

70. Appellate Body Report, United States-Laws, Regulations and Methodology for Calculating Dumping Margins (Zeroing), WTO Doc. WT/DS294/AB/R 99 (adopted Apr. 18, 2006).

71. Appellate Body Report, United States - Measures Relating to Zeroing and Sunset Reviews, WTO Doc. WT/DS322/AB/R (adopted Jan. 9, 2007).

72. Transaction to Transaction.

73. Id.

74. Anti-dumping disputes: DS368, DS379, DS449, DS471, DS515, available at https://www. wto.org/english/tratop_e/dispu_e/dispu_by_country_e.htm\#complainant.

75. Appellate Body Report, United States - Definitive Anti-Dumping and Countervailing Duties on Certain Products from China, WTO Doc. WT/DS379/AB/R (adopted Mar. 11, 2011).

76. Id.

77. Panel Report, United States - Countervailing and Anti-dumping Measures on Certain Products from China, 128, WTO. Doc. WT/DS449/R (adopted Mar. 27, 2014).

78. Panel Report, United States - Certain Methodologies and their Application to AntiDumping Proceedings Involving China, 120, WTO Doc. WT/DS471/R (adopted Oct. 19, 2016).

79. Id.

80. Id.

81. T. Prusa \& E. Vermulst, United States-Certain Methodologies and Their Application to Anti-Dumping Proceedings Involving China: Nails in the Coffin of Unfair Dumping Margin Calculation Methodologies, 18(2) World Trade Rev. 1-21 (2019).

82. Id.

83. Panel Report, United States - Anti-Dumping Measures Applying Differential Pricing Methodology to Softwood Lumber from Canada, 37, WTO Doc. WT/DS534/R (adopted Apr. 9, 2019).

84. A. Blazyte, Export Trade in China - Statistics \& Facts, available at https://www.statista. com/topics/1456/export-in-china/\#: :text=In\%202009\%2C\%20China\%20overtook\%20 Germany,of $\% 20$ its $\% 20$ exports $\% 20$ and $\% 20$ imports.

85. L. Lau, The China-US Trade War and Future Economic Relations, 2(2) CHINA \& THE WORLD 22 (2019), available at https://www.worldscientific.com/doi/epdf/10.1142/S25917 29319500123.

86. Id.

87. Timeline: Key dates in the U.S.-China trade war, available at https://www.reuters. com/article/us-usa-trade-china-timeline/timeline-key-dates-in-the-u-s-china-trade-war- 
idUSKBN1ZE1AA.

88. Id.

89. C. Bown, US-China Trade War Tariffs: An Up-to-Date Chart, PIIE Charts (Feb. 14, 2020), available at https://www.piie.com/research/piie-charts/us-china-trade-war-tariffs-datechart.

90. Id.

91. Id.

92. Id.

93. See The US-China Trade War: A Timeline, ChinA Briefing, Aug. 25, 2020, available at https://www.china-briefing.com/news/the-us-china-trade-war-a-timeline.

94. E. Olaniyi, The Effects of US-China Trade War and Trumponomics, 7(1) F. SCIENTIAE OECONOMIA 47-55 (2019).

95. Id.

96. M. Waugh, The Consumption Response to Trade Shocks: Evidence from the US-China Trade War (National Bureau of Economic Research No. w26353, 2019).

97. L. Colback, How to Navigate the US-China Trade War, FIN. TIMES, available at https:// www.ft.com/content/6124beb8-5724-11ea-abe5-8e03987b7b20.

98. Id.

99. S. Mintzer \& D. Layton \& T. Lee, Proposed Changes to Antidumping and Countervailing Duty Regulations Would Make Proceedings More Efficient and Create New Enforcement Mechanisms (Aug. 14, 2020), available at https://www.mayerbrown.com/en/perspectivesevents/publications/2020/08/proposed-changes-to-antidumping-and-countervailingduty-regulations-would-make-proceedings-more-efficient-and-create-new-enforcementmechanisms.

100. European Commission, Countries and Regions, available at https://ec.europa.eu/ trade/policy/countries-and-regions/countries/vietnam/\#: :text=The\%20European\%20 Union\%20and\%20Vietnam,Council\%20on\%2030\%20March\%202020.

101. Id.

102. Executive Order No. 13936, 3 C.F.R. Guidance on Marking of Goods of Hong Kong, U.S. Customs and Border Protection, available at https://www.cbp.gov/trade/rulings/frequentlyasked-questions-guidance-marking-goods-hong-kong-executive-order-13936? $\mathrm{ga}=2.69427856 .1287851153 .1597626421-308187796.1597626421$.

103. E. Lai, The US-China Trade War, the American Public Opinions and Its Effects on China, 7(2) Econ. Political Stud. 169-84 (2019).

104. D. Steinbock, US-China Trade War and Its Global Impacts, 4(4) China Q. INT'L STRATEGIC STUD. 515-42 (2018), available at https://www.researchgate.net/publication/332623631_ US-China_Trade_War_and_Its_Global_Impacts.

105. China Balance of Trade, TRADING ECONOMICS, available at https://tradingeconomics.com/ china/balance-of-trade. 
106. Id.

107. Id.

108. Panel Report, United States - Tariff Measures on Certain Goods from China, 65, WTO Doc. WT/DS543/R (adopted Sept. 15, 2020).

109. Id.

110. Supra note 103, at 172.

111. Id.

112. Supra note 104, at 521.

113. The North American Free Trade Agreement.

114. Rajesh Sharma, WTO Appellate Body at Cross Roads: Options and Alternatives, in THE Appellate Body of the WTO and its Reform 239-54 (Lo et al. eds., 2020).

115. Interim appeal arrangement for WTO disputes becomes effective, available at https:// trade.ec.europa.eu/doclib/press/index.cfm?id=2143.

116. A. Herrero, From Globalization to Deglobalization: Zooming Into Trade, Bruegel Special Report 33-52 (2019).

117. Id.

118. US Dept. of Treasury, Treasury Sanctions Individuals for Undermining Hong Kong's Autonomy, Press Release, Aug. 7, 2020 available at https://home.treasury.gov/news/ press-releases/sm1088.

119. What's in the U.S.-China Phase 1 Trade Deal, Reuters, Jan. 16, 2020, available at https:// www.reuters.com/article/us-usa-trade-china-details-factbox-idUSKBN1ZE2IF.

120. W. Tan, US-China Relations at a Low as 'Blame-shifting' Sets Back War against Virus, CNBC, Apr. 21, 2020 available at https://www.cnbc.com/2020/04/22/coronavirus-trumpblames-china-virus-impact-on-trade-war.html.

121. W. Tan, US-China Relations at a Low as 'Blame-shifting' Sets Back War against Virus, CNBC, Apr. 21, 2020 available at https://www.cnbc.com/2020/04/22/coronavirus-trumpblames-china-virus-impact-on-trade-war.html.

122. Id. at 2.

123. Supra note 99.

124. USITC, Open Data, available at https://www.usitc.gov/data/index.htm.

125. For details, see S. Cho \& T. Lee, Double Remedies in Double Courts, 26(2) EuR. J. INT'L L. 519-35 (2015).

126. Supra note 119.

127. The China-wide entity rate is $1731 \%$ which is a record. Also, another investigation was initiated against multiple countries in April 2020. See US Department of Commerce, U.S. Department of Commerce Finds Dumping of Imports of Mattresses from China, Press Release, Oct.18, 2019, available at https://www.commerce.gov/news/pressreleases/2019/10/us-department-commerce-finds-dumping-imports-mattresses-china; U.S. Department of Commerce Initiates Antidumping Duty and Countervailing Duty 
Investigations of Imports of Mattresses from Multiple Countries, International Trade Administration, Apr. 21, 2020, available at https://www.trade.gov/press-release/usdepartment-commerce-initiates-antidumping-duty-and-countervailing-duty-4.

128. Supra note 108.

129. WTO, Chronological List of Disputes Cases, available at https://www.wto.org/english/ tratop_e/dispu_e/dispu_status_e.htm.

130. Id.

131. DS543, DS544, DS562, DS563, DS565, DS587. See WTO, Chronological List of Disputes Cases, available at $\mathrm{https} / / \mathrm{www}$.wto.org/english/tratop_e/dispu_e/dispu_status_e.htm.

132. Tao Liu \& Wing Thye Woo, Understanding the US-China Trade War, 11(3) CHINA ECoN. J. 319-40 (2018). 
